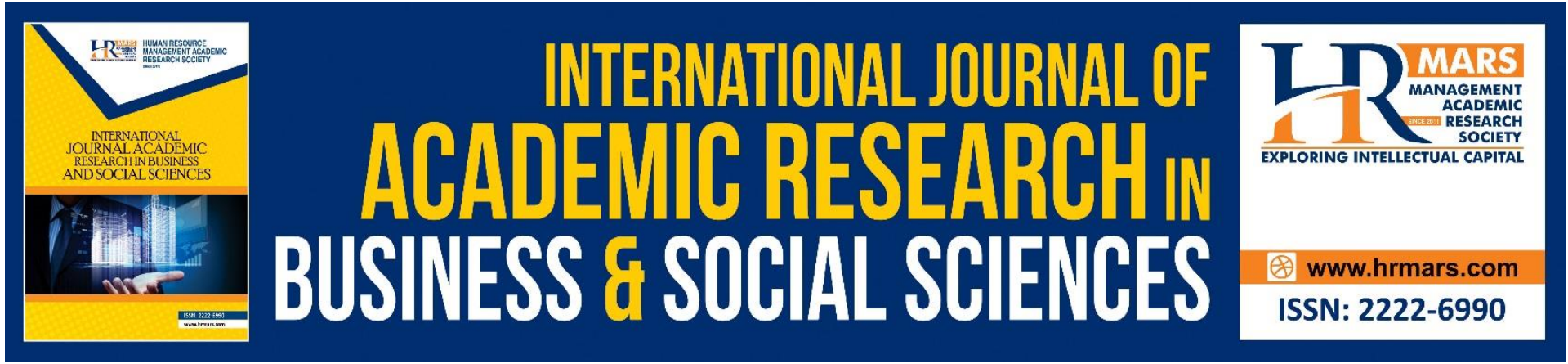

\title{
The Need for Instrument Development to Measure Teachers' Efficacy in Implementing Classroom Assessment
}

Rodhiana Rosli, Siti Eshah Mokhsein, Zahari Suppian

To Link this Article: http://dx.doi.org/10.6007/IJARBSS/v11-i7/10528

DOI:10.6007/IJARBSS/v11-i7/10528

Received: 21 May 2021, Revised: 25 June 2021, Accepted: 15 June 2021

Published Online: 29 July 2021

In-Text Citation: (Rosli et al., 2021)

To Cite this Article: Rosli, R., Mokhsein, S. E., \& Suppian, Z. (2021). The Need for Instrument Development to Measure Teachers' Efficacy in Implementing Classroom Assessment. International Journal of Academic Research in Business and Social Sciences, 11(7), 699-706.

Copyright: @ 2021 The Author(s)

Published by Human Resource Management Academic Research Society (www.hrmars.com)

This article is published under the Creative Commons Attribution (CC BY 4.0) license. Anyone may reproduce, distribute, translate and create derivative works of this article (for both commercial and non-commercial purposes), subject to full attribution to the original publication and authors. The full terms of this license may be seen

at: http://creativecommons.org/licences/by/4.0/legalcode

Vol. 11, No. 7, 2021, Pg. 699 - 706

http://hrmars.com/index.php/pages/detail/IJARBSS

JOURNAL HOMEPAGE

Full Terms \& Conditions of access and use can be found at http://hrmars.com/index.php/pages/detail/publication-ethics 


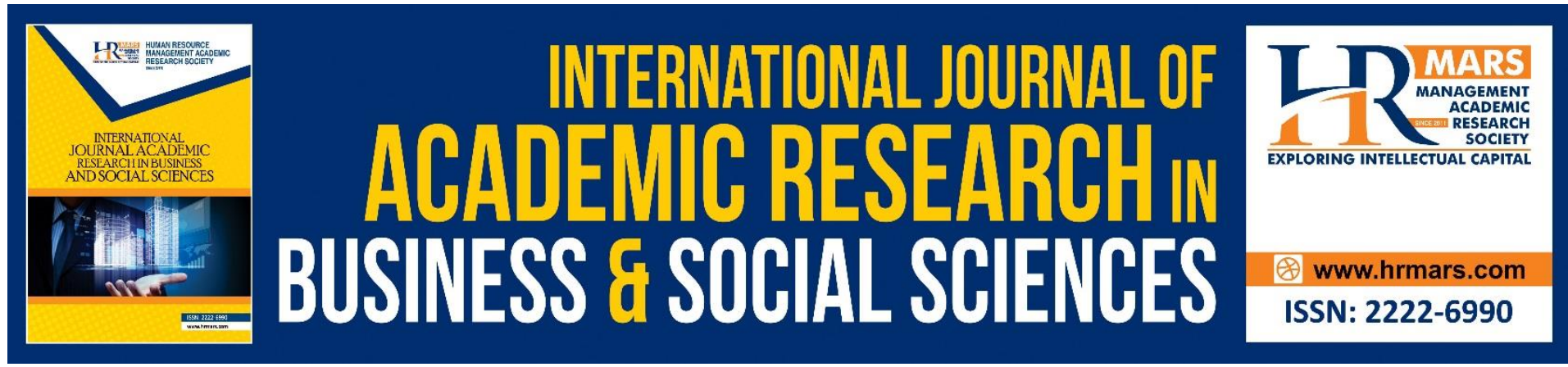

\title{
The Need for Instrument Development to Measure Teachers' Efficacy in Implementing Classroom Assessment
}

\author{
Rodhiana Rosli, Siti Eshah Mokhsein, Zahari Suppian \\ Department Of Educational Studies Faculty of Human Development Universiti Pendidikan \\ Sultan Idris, Tanjung Malim, Perak, Malaysia.
}

\begin{abstract}
This study aims to discuss the need for instrument development to measure teachers' efficacy in implementing classroom assessment. This study found three conditions for developing teachers' efficacy instrument: to determine teachers' efficacy in implementing classroom assessment, plan teachers' professional development training, and no specific instrument to measure teachers' efficacy in implementing classroom assessment. Therefore, to measure teachers' efficacy in implementing classroom assessment, a comprehensive and up-to-date instrument with higher validity and reliability needs to be developed using the Rasch Measurement Model.
\end{abstract}

Keywords: Classroom Assessment, Teachers' Efficacy, Instrument, Validity, Reliability, Rasch Measurement Model

\section{Introduction}

Assessment is an essential process to identify students' learning development. Along with the desire to change the focus of learning from examination-oriented to focus on students' learning development, classroom assessment is implemented in all primary schools in Malaysia starting from 2019 (Curriculum Development Division, 2018). However, the implementation of classroom assessment was done inaccurately and deviated from its original purpose (Isa et al., 2020; Box et al., 2015; Salleh et al., 2019; Noh et al., 2020). That problem arises because, there are some problems experienced by teachers while performing classroom assessment such as lack of confidence in practising assessment skills, unable to provide useful feedback and time constraints to diversify assessment strategies to meet the diverse abilities of students (Dorin \& Yasin, 2019; Salleh et al., 2019; Jusoh \& Mahamod, 2019). These factors reflect the low of teachers' efficacy in implementing classroom assessment.

Teachers' efficacy can influence teachers' confidence in performing a task, including assessing students' task. Therefore, the teachers must identify their efficacy so that teachers can overcome existing weaknesses. To determine the level of teachers' efficacy, an instrument that meets the validity and reliability requirements needs to be developed. 
Therefore, the purpose of this paper is to identify the need to develop an instrument that can measure teachers' efficacy in implementing classroom assessment.

\section{Literature Review}

The researchers conducted a literature review to provide a clear picture of the concepts discussed in this article. This section will explain the literature review related to classroom assessment, teachers' efficacy and instrument.

\section{i. Classroom Assessment}

Assessment is a process performed by teachers to obtain information to conclude students' learning development decisions. Teachers can use information obtained through the assessment to plan further learning according to students' needs (Brookhart, 2003; Fives \& Barnes, 2020). Besides, the assessment results are also essential to determine the effectiveness of teachers' teaching. Therefore, the assessment must be done continuously in the classroom under the teacher's supervision (Ghazali et al., 2018), and it is known as Classroom Assessment.

Most researchers conceptualize classroom assessment as a process implemented by teachers to collect, synthesize, interpret, and use it to make decisions related to students' learning performance and teachers' teaching performance (Brookhart, 1997; Fives \& Barnes, 2020; Russell \& Airasian, 2012). The information obtained during the classroom assessment process is crucial to help teachers improve students' learning mastery. This concept is also applied in the implementation of classroom assessment in Malaysia, as explained in the Classroom Assessment Implementation Handbook (Curriculum Development Division, 2019).

Classroom assessment is the most effective type of measurement in influencing students' learning and motivation (Fives \& Barnes, 2020; McMillan, 2018). Therefore, teachers need to have motivation and ability in implementing classroom assessment (Bruun \& Evans, 2020). Thus, self-efficacy becomes an important aspect that can help teachers increase their confidence to implement classroom assessment effectively and accurately.

\section{ii. Teachers' Efficacy}

Teachers' efficacy in implementing classroom assessment refers to teachers' confidence in planning, organizing, and carrying out assessment-related activities (Hartell, 2018), which coincides with the concept of self-efficacy by Bandura (1997). According to Bandura (1997), teachers' efficacy is the teacher's confidence in performing tasks successfully. In implementing classroom assessment, teachers need to have the confidence in implementing the assessment process by meeting the standards set out in the Curriculum and Assessment Standards Document.

Self-efficacy will guide and motivate teachers' actions based on their belief in their ability to implement the assessment process and continue educational activities, influencing students' learning (Hartell, 2018). Studies related to teachers' efficacy in implementing classroom assessment are rarely done (Green, 2019) compared to teachers' efficacy studies in other aspects such as teaching, leadership, job satisfaction and emotional intelligence. Therefore, the study's proposed implementation in this aspect, especially the development 
of an instrument, should be done to measure the extent of teachers' efficacy in carrying out classroom assessment.

\section{iii. Instrument}

Teachers' efficacy instruments in implementing classroom assessments were developed to be administered by teachers and school administrators to identify the extent to which teachers' efficacy in implementing classroom assessment. This instrument will help teachers and school administrators to identify problems encountered in implementing the classroom assessment process. In Illinois, teachers' assessment efficacy instrument is provided to identify teachers' difficulties in implementing classroom assessment to enable professionalism development programs to be implemented to improve teachers' efficacy (Wolfe et al., 2007).

The instrument acts as a measuring tool to determine the teacher's efficacy where a teacher's efficacy will indicate the extent of the teacher's ability to perform classroom assessment. Researchers identify the requirement to develop an instrument with a valid and reliable instrument to detect teachers' problems in implementing classroom assessment. Existing problems reflect the inability of teachers to perform classroom assessment and need to be addressed. In this study, the instrument is defined as a measurement tool for teachers and school administrators to assess teachers' efficacy in conducting classroom assessment.

\section{Methodology}

In particular, this study is an overview of the need to develop an instrument to measure teachers' efficacy in implementing classroom assessment. This study aims to identify the need for instrument development to measure teachers' efficacy in implementing classroom assessment. This study does not involve respondents, and the researchers will discuss the study's findings based on the literature review.

\section{Findings}

The findings of this study indicate that all teachers do not readily accept changes in assessment practices. Difficult in getting change is associated with low self-efficacy, which can hinder classroom assessment effectiveness (Green, 2019). Therefore, the need to develop an instrument that can measure teachers' efficacy in implementing classroom assessments are as follows:

\section{i. To identify teachers' efficacy}

Teachers' efficacy is vital in the process of implementing classroom assessment. Teachers with high self-efficacy will do better planning in implementing classroom assessment (McMillan, 2013) to meet students' needs. In the context of the definition, teachers' efficacy refers to teachers' beliefs in their ability to perform tasks such as completing the assessment process to determine students' learning development (Bandura, 1997; Green, 2019; Vivian \& Falkner, 2018). Teachers' efficacy also refers to the teacher's ability to improve students' achievement according to set standards (Bandura, 1997; Green, 2019) to ensure that teachers can accurately identify students' learning development. Therefore, teachers' efficacy must be determined either through self-assessment or assessed by school administrators using a reliable and valid instrument. Identifying teachers' efficacy is essential to enable teachers to identify their self-efficacy level and then change their behaviour to successfully implement classroom assessment. 


\section{To plan teachers' professional development training}

Identifying teachers' efficacy in implementing classroom assessment is like analyzing teachers' strengths and weaknesses in implementing classroom assessment. The information obtained will provide adequate information for school administrators to plan specific training to improve teachers' professionalism, especially in the assessment aspect. If an instrument can analyze which parts teachers can't do in a classroom assessment process, educational administrators must plan training. Information from instrument data analysis will help school administrators to plan beneficial programs as has been done in foreign countries such as Illinois (Wolfe et al., 2007) and Europe (Bruun \& Evans, 2020).

\section{ii. No specific instrument}

Previous researchers have indeed done studies related to self-efficacy a lot. However, most studies focus more on teachers' efficacy in teaching practice, job satisfaction, leadership, training and willingness to change. Most previous studies also only adapted the Teacher Self Efficacy Scale (TSES) instrument developed by Tschannen-Moran and Hoy (2001) in their research. The difficulty in finding instruments that directly measure teachers' efficacy in implementing classroom assessment indicates the need to develop an instrument that can measure teachers' efficacy in implementing classroom assessment. Teachers' efficacy in implementing classroom assessment is essential because self-efficacy is an obstacle to assessing assessment practices (Green, 2019). Thus, there is a need to develop teachers' efficacy instrument by focusing on teachers' efficacy in implementing classroom assessment.

Hence, the development of specific teachers' efficacy instrument to determine teachers' efficacy in implementing classroom assessment will help future researchers determine the level of teachers' efficacy and a guide and reference for other researchers in this field. Besides, this study also contributes to more systematic documentation that involves planning and developing an instrument.

\section{Discussion}

Researchers have found no specific instruments to measure teachers' efficacy in implementing classroom assessment in the Malaysian context. Therefore, an instrument that meets the validity and reliability aspects needs to be developed so that teachers can identify their efficacy in implementing the assessment process to take follow-up action.

Teachers' efficacy reflects the confidence of teachers in implementing classroom assessments. Teachers' efficacy is required at all classroom assessment stages, specifically during the assessment process's planning and implementation stage. High level of teachers' efficacy in planning classroom assessments helps teachers overcome difficulties in planning classroom assessments. It involves taking into account aspects of student skills (Adhikari, 2020; Yan \& Cheng, 2015) so that assessment tasks are designed to suit students' abilities and meet standard practices.

Similarly, at the implementation stage, teachers' efficacy is needed to increase teachers' confidence in diversifying assessment methods appropriate to students' needs without neglecting the standards set out in the Curriculum and Assessment Standard Document. Teachers' ability to diversify assessment methods is important to encourage 
interaction during the assessment process to enable teachers to identify students' strengths and weaknesses as a source to develop students' potential (Black \& Wiliam, 2009).

Therefore, teachers' efficacy in implementing classroom assessment should be taken into account so that the implementation of classroom assessment runs as intended by the Ministry of Education Malaysia. Having high self-efficacy will encourage teachers to effectively assess students and contribute quality to our country's education.

\section{Conclusion And Recommendation}

Teachers' efficacy instrument that meets the validity and high-reliability aspects should be developed to measure teachers' efficacy in implementing classroom assessment. Rasch measurement model should be used to develop an instrument that meets the validity and reliability aspects

The Rasch measurement model is a probability model designed to answer questions about an individual's ability to answer items with specific difficulty parameters and the probability that they will answer the item correctly (Bond \& Fox, 2015; Mokhsein, 2018). This probability increases in line with the values of some other item parameters such as difficulty parameters, discrimination parameters, and guess parameters through the Rasch measurement model.

Also, only Rasch measurement models can solve problems such as producing linear measurements, can use all types of data, detect errors or outliers and provide separate or independent measurement instruments for observed object parameters (Aziz et al., 2015). Not only that, but the Rasch measurement model is also capable of detecting model inaccuracies and producing repeated measurements.

\section{Acknowledgement}

Our special thanks go to Sultan Idris Education University (UPSI) for sponsored our conference registration fee. The first author would like to express special thanks to the Ministry of Education Malaysia for the scholarship. Finally, we would like to express our appreciation to all the dedicated committee members of ICIRMEST2021.

\section{Corresponding Author}

Siti Eshah Mokhsein

Department of Educational Studies Faculty of Human Development Universiti Pendidikan

Sultan Idris Malaysia

Email: eshah@fpm.upsi.edu.my

\section{References}

Adhikari, K. P. (2020). Self-efficacy beliefs among school mathematics teachers of Nepal. International Journal of Research -GRANTHAALAYAH, 8(07), 192-204

Aziz, A. A., Masodi, M. S., \& Zaharim, A. (2015). Asas model pengukuran Rasch: Pembentukan skala \& struktur pengukuran. Penerbit Universiti Kebangsaan Malaysia

Bandura, A. (1997). Theoretical Perspectives: the nature of human agency. In Self-efficacy: The exercise of control (p. 3). https://doi.org/10.1007/SpringerReference_223312

Black, P. J., \& Wiliam, D. (2009). Developing the theory of formative assessment. Educational 
Assessment, Evaluation and Accountability, 1(1), 1-40.

https://doi.org/10.1007/s11092-008-9068-5

Bond, T. G., \& Fox, C. M. (2015). Applying the Rasch model: Fundamental measurement in the human sciences. In Routledge (Vol. 3). https://doi.org/10.4324/9781410614575

Box, C., Skoog, G., \& Dabbs, J. M. (2015). A case study of teacher personal practice assessment theories and complexities of implementing formative assessment. American Educational Research Journal, 52(5), 956-983.

https://doi.org/10.3102/0002831215587754

Brookhart, S. M. (1997). A theoretical framework for the role of classroom assessment in motivating student effort and achievement. Applied Measurement in Education, 10(2), 161-180. https://doi.org/10.1207/s15324818ame1002_4

Brookhart, S. M. (2003). Developing measurement theory for classroom assessment purposes and uses. Educational Measurement: Issues and Practice, 22(4), 5-12. https://doi.org/10.1111/j.1745-3992.2003.tb00139.x

Bruun, J., \& Evans, R. H. (2020). Network analysis of survey data to identify non-homogeneous teacher self-efficacy development in using formative assessment strategies. Education Sciences, 10(3), 1-20. https://doi.org/10.3390/edieducsci10030054

Curriculum Development Division. (2018). Panduan Pelaksanaan Pentaksiran Bilik Darjah (PBD) bagi Murid Tahap 1. Ministry of Education

Curriculum Development Division. (2019). GariPanduan Pelaksanaan Pentaksiran Bilik Darjah (PBD) bagi Murid Tahap 1 (2nd ed). Ministry of Education

Dorin, A. D., \& Yasin R. M. (2019). Tahap kesediaan guru terhadap pelaksanaan pentaksiran bilik darjah (PBD). The International Conference of Future Education and Advances (ICOFEA) 2019, 8-15

Fives, H., \& Barnes, N. (2020). Navigating the complex cognitive task of classroom assessment. Teaching and Teacher Education, 92, 1-17. https://doi.org/10.1016/j.tate.2020.103063

Ghazali, N. H. C. M., Rabi, N. M., Hassan, N. M., \& Wahab, N. A. (2018). A confirmatory factor analysis of classroom assessment practises scale in a Malaysian context. International Journal of Academic Research in Progressive Education and Development, 7(3), 516529. https://doi.org/10.6007/IJARPED/v7-i3/4570

Green, F. (2019). An exploration into the value of formative assessment and the barriers associated with the implementation of formative strategies. In Rethinking teacher education for the 21st century (pp. 203-222). https://doi.org/10.2307/j.ctvpb3xhh.17

Hartell, E. (2018). Teachers' self-efficacy in assessment in technology education. In Handbook of Technology Education (pp. 785-800). https://doi.org/10.1007/978-3-319-44687-5

Isa, A. M., Mydin, A., Abdullah, A. G. K., \& Rasidi, W. F. M. (2020). Transformasi pendidikan tahap 1: Peperiksaan ke pentaksiran bilik darjah (PBD), kesan terhadap autonomi guru. In Habidin, N.F., Chik, T.W.T., Yong, S.Y.O., Muhammad, U.A., \& Fuzi, N.M., Isu dan cabaran dalam pendidikan: Strategi dan inovasi (pp. 218-231). Kaizentrenovation Sdn. Bhd.

Jusoh, W. N. A. S. W., \& Mahamod, Z. (2019). Tahap pengetahuan, pelaksanaan dan masalah guru dalam melaksanakan penilaian formatif dalam pentaksiran bilik darjah (PBD) Bahasa Melayu Tahap 1. The International Conference of Future Education and Advances (ICOFEA) 2019, 788-795

McMillan, J. H. (2013). Research on classroom assessment and research. Sage Publications McMillan, J. H. (2018). Classroom assessment: principles and practice that enhance student 
learning and motivation (7th ed.). Pearson Education, Inc. https://doi.org/August 3, 2017

Mokhsein, S. E. (2018). Aplikasi teori respons item dalam penyelidikan. Penerbit Universiti Pendidikan Sultan Idris.

Noh, N. M., Halili, S. H., \& Siraj, S. (2020). Analisis faktor kekangan pembelajaran berasaskan reka bentuk dalam kalangan guru berdasarkan fuzzy delphi method. Jurnal Kurikulum \& Pengajaran Asia Pasifik, 8(1), 33-42.

Russell, K. M., \& Airasian, W. P. (2012). Classroom assessment concepts and applications (7th ed). McGraw-Hill

Salleh, M., Sarkowi, A., Jafar, M. F., Arif, Z. M., \& Hamid, H. A. (2019). Tahap literasi guru terhadap pendekatan dalam pentaksiran bilik darjah. Seminar Antarabangsa Isu-Isu Pendidikan (ISPEN 2019), 12-24. https://doi.org/10.1017/СВO9781107415324.004

Tschannen-Moran, M., \& Hoy, A. W. (2001). Teacher efficacy: Capturing an elusive construct. Teaching and Teacher Education, 17(7), 783-805. https://doi.org/10.1016/S0742051X(01)00036-1

Vivian, R., \& Falkner, K. (2018). A survey of Australian teachers' self-efficacy and assessment approaches for the K-12 digital technologies curriculum. Computing Education (WiPSCE '18), October 4-6, 2018, Potsdam, Germany. https://doi.org/10.1145/3265757.3265762

Wolfe, E. W., Viger, S. G., Jarvinen, D. W., \& Linksman, J. (2007). Validation of scores from a measure of teachers' efficacy toward standards-aligned classroom assessment. Educational and Psychological Measurement, 67(3), 460-474. https://doi.org/10.1177/0013164406292091

Yan, Z., \& Cheng, E. C. K. (2015). Primary teachers' attitudes, intentions and practices regarding formative assessment. Teaching and Teacher Education, 45, 128-136. https://doi.org/10.1016/j.tate.2014.10.002 